\title{
THE OCCURRENCE AT PLYMOUTH OF DICTYOCOTYLE COELIACA NYBELIN, 1941 (TREMATODA: MONOGENEA)
}

\author{
By J. LLEWELLYN \\ Department of Zoology and Comparative Physiology, University of Birmingham \\ and J. E. GREeN \\ The Plymouth Laboratory
}

(Plate I)

Dictyocotyle coeliaca is a somewhat unusual monogenetic trematode in that it is endoparasitic and not ectoparasitic, as are most monogeneans. It was first described by Nybelin (194I) from two specimens, one of which had been collected by Swenander in 1905 from the coelom of Raia radiata caught at Trondhjem, and the other collected by Nybelin himself from $R$. lintea caught at Göteborg. Later, according to Sproston (1946), Mr Quinten Geering at Cambridge found three trematodes firmly attached to the liver of a young Raia sp. from Plymouth. These parasites were deposited in the British Museum, where they were provisionally identified as damaged specimens of Calicotyle kroyeri, a common parasite of the cloaca of various species of Raia. However, these specimens were subsequently examined by Dr Brinkmann (1952) of Bergen, and he, having seen the type material, was able to identify the Plymouth specimens as Dictyocotyle coeliaca.

Two parasites collected in the Zoology Department at Sheffield University from the outside of the stomach of Raia clavata, believed to have been landed at Brixham, were identified by Dawes (1948) as Nybelin's species, but Dawes regarded the species as belonging to the genus Calicotyle.

Hunter \& Kille (1950) examined rays brought from Scottish fishing grounds into the Zoology Department at Edinburgh University, and found Dictyocotyle coeliaca in sixteen of fifty-five specimens of Raia naevus and in thirty-one of seventy-three specimens of $R$. radiata, but none in $R$. batis, $R$. montagui, $R$. brachyura, $R$. clavata and $R$. fullonica. These authors gave a description of Dictyocotyle coeliaca and compared the parasite with Calicotyle kroyeri.

In the present observations, examinations have been made of specimens of the four species of Raia commonly landed at Plymouth, in the period May I 955 to August 1956 inclusive. The coelom and viscera of each host specimen were searched for the presence of Dictyocotyle coeliaca, and the results are included in Table $\mathrm{I}$. 
Of the thirty-five infected specimens of Raia naevus, nineteen were males and sixteen were females. The mean infestation of parasites per fish was 3.97 , and the maximum number of parasites collected from a single host specimen was twenty-two. There appeared to be no particular site of infestation within the coelom, and living specimens of the trematode were collected, at periods varying from I to $\mathrm{I} 8 \mathrm{hr}$ after the death of the host, from all the inner surfaces of the body wall, and less frequently, from the viscera.

\begin{tabular}{|c|c|c|}
\hline Host & $\begin{array}{l}\text { No. of } \\
\text { specimens } \\
\text { examined }\end{array}$ & $\begin{array}{c}\text { No. } \\
\text { infected }\end{array}$ \\
\hline $\begin{array}{l}\text { Raia naevus } \\
\text { R. clavata } \\
\text { R. montagui }(=R . \text { maculata })\end{array}$ & $\begin{array}{l}135 \\
478 \\
420\end{array}$ & $\begin{array}{r}35 \\
0 \\
0\end{array}$ \\
\hline R. brachyura & 34 & $\circ$ \\
\hline
\end{tabular}

On several occasions specimens of both Dictyocotyle coeliaca and Calicotyle krøyeri have been found in the same individual Raia naevus, the former in the coelom and the latter in the cloaca. Photographs illustrating the differences between the two parasites, previously noted by Hunter \& Kille, are included in P1. I, figs. I and 2.

It may be concluded then that Dictyocotyle coeliaca is at least as common in Raia naevus at Plymouth (about $26 \%$ infestation) as are most other monogeneans on their respective hosts (see table of frequencies in Llewellyn, I956); the remarkable feature is that it has escaped attention, since $R$. naevus, along with other rays, is frequently supplied to University Departments for class dissection.

In view of the absolute restriction of Dictyocotyle coeliaca to Raia naevus in over 1000 Raia specimens examined at Plymouth in the present study, and to $R$. naevus and $R$. radiata in Hunter \& Kille's (I950) study of I8I specimens of rays from Scottish waters, it seems distinctly possible that the Brixham host ('Raia clavata') of the material sent to Dawes (1948) had been mis-identified.

\section{SUMMARY}

In a sample of over 1000 rays belonging to four species of Raia examined at Plymouth between May I955 and August 1956, the 'very rare' monogenetic trematode Dictyocotyle coeliaca Nybelin, I94I (total of four previous records) was found in the coelom of thirty-five out of 135 specimens of Raia naevus, but absent from $478 R$. clavata, $420 R$. montagui and $34 R$. brachyura. 


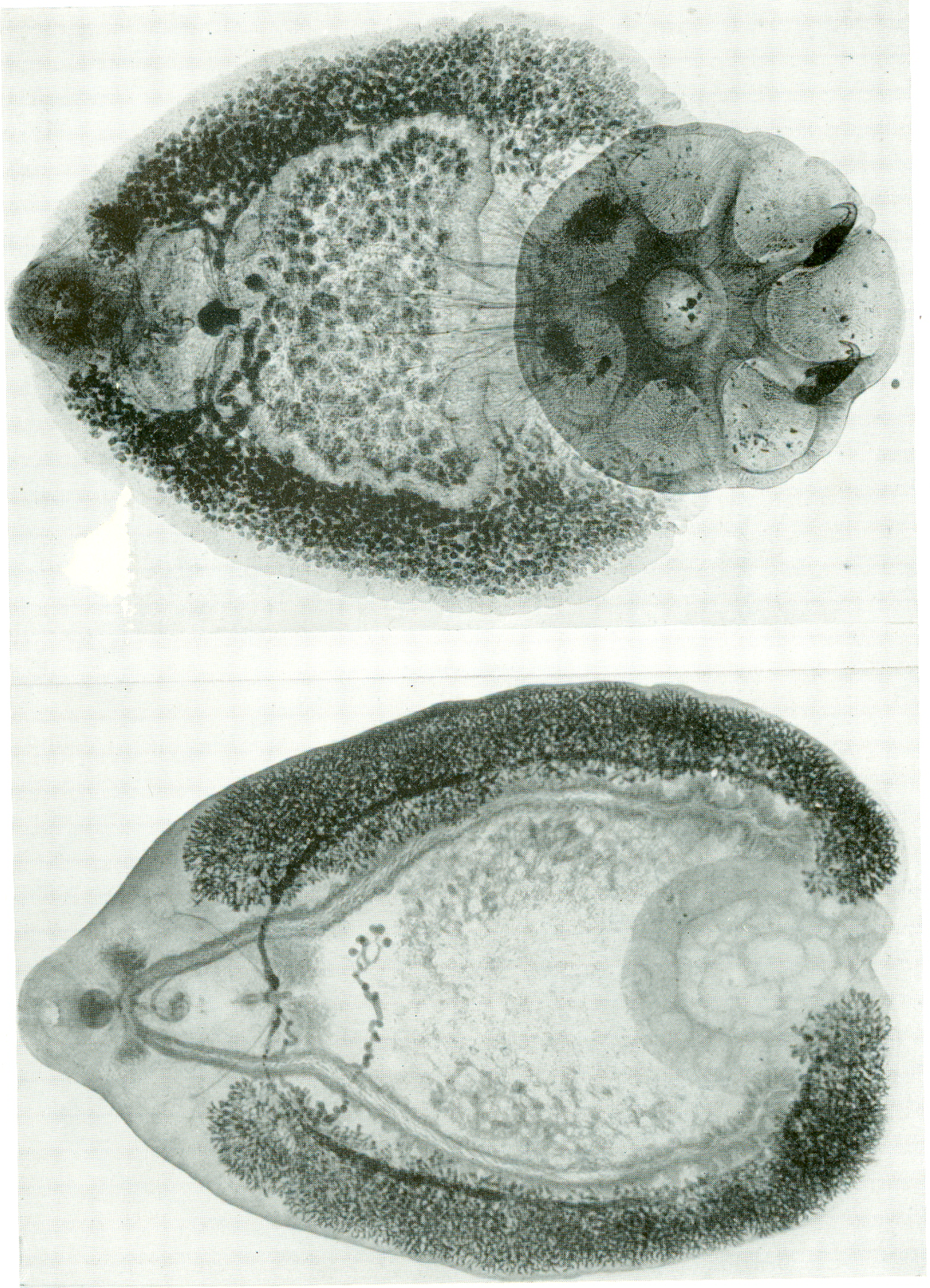

(Facing p. 78) 


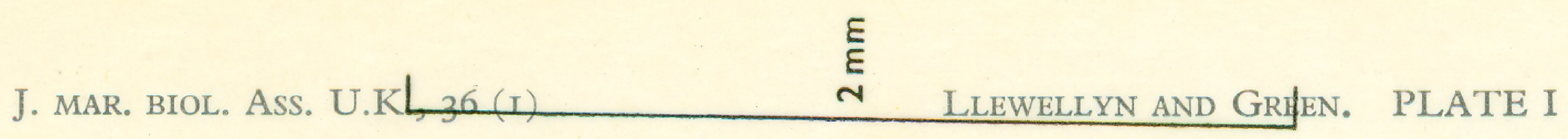

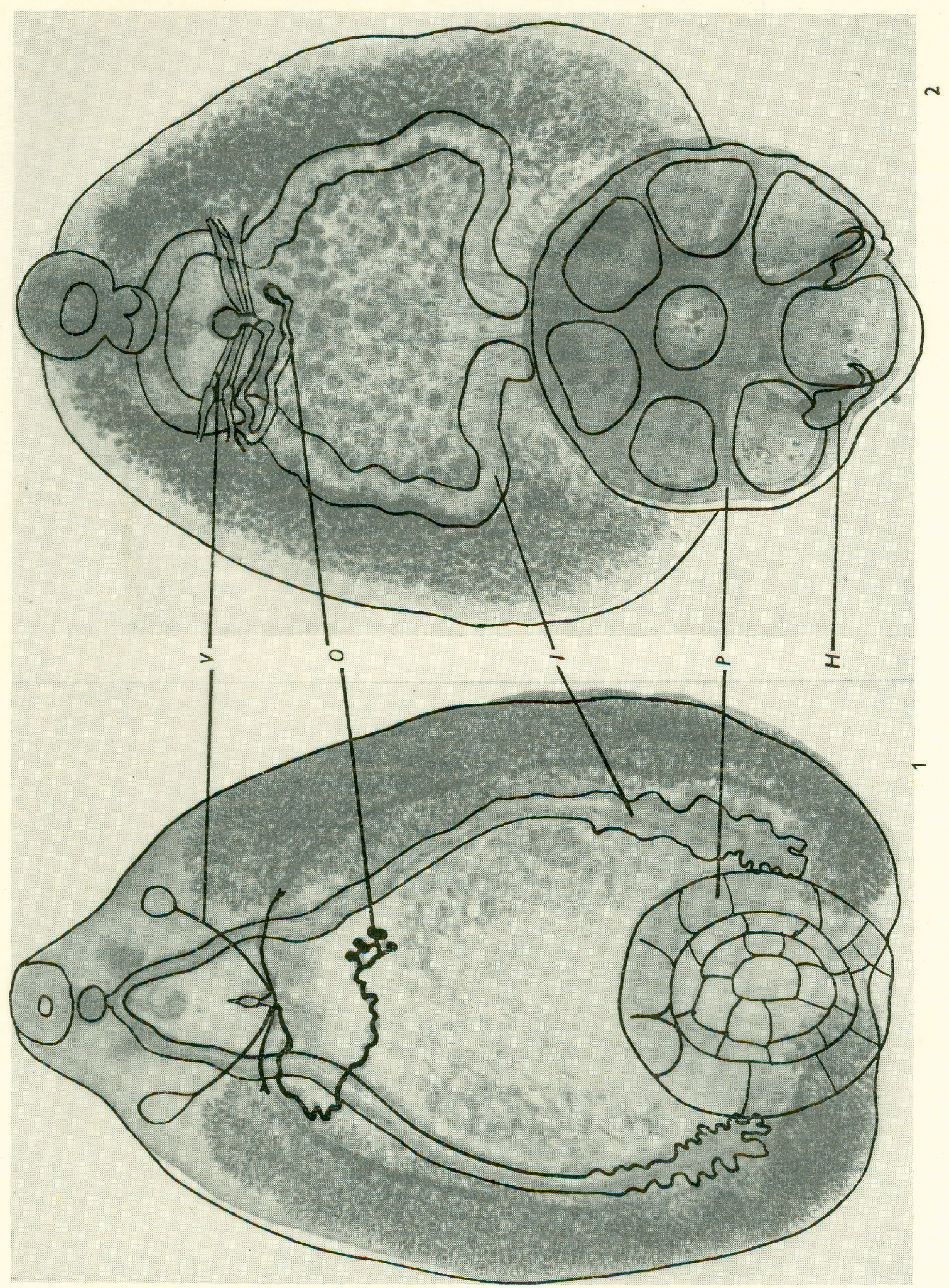

(Facing p. 78)

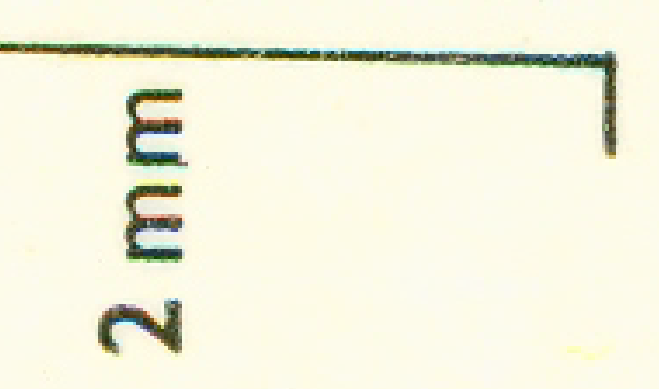




\section{REFERENCES}

Brinkmann, A., 1952. Fish trematodes from Norwegian Waters. Univ. Bergen Arb. naturv. $R$., No. $\mathrm{I}$.

DAwES, B., 1948. A rare coelom-dwelling trematode. Nature, Lond., Vol. I6I, p. 642.

Hunter, G. C. \& Kille, R. A., I950. Some observations on Dictyocotyle coeliaca Nybelin, 194I. F. Helminth., Vol. 24, pp. I5-22.

LleWELlyN, J., 1956. The host specificity, micro-ecology, adhesive attitudes, and comparative morphology of some trematode gill parasites. F. mar. biol. Ass. U.K., Vol. 35, pp. I13-27.

Nybelin, O., I94I. Dictyocotyle coeliaca n.g. n.sp. Ein leibeshöhlebewohnender monogenetischer Trematode. Göteborgs VetenskSam. Handl., Följ. vr, Ser. B, Bd I, No. 3, 19 pp.

Sproston, N. G., 1946. A synopsis of the monogenetic trematodes. Trans. zool. Soc. Lond., Vol. 25, pp. 185-600.

\section{EXPLANATION OF PLATE I}

A comparison of the morphology of Dictyocotyle coeliaca Nybelin, I94I with that of Calicotyle krøyeri Diesing, I850. Fig. I. Dictyocotyle coeliaca. Fig. 2. Calicotyle kroyeri. I, posterior ends of intestinal caeca of Dictyocotyle sacculated and end well behind anterior edge of posterior adhesive organ; not sacculated in Calicotyle, and end in front of anterior edge of posterior adhesive organ. $\mathrm{H}$, hooks present in Calicotyle, absent in Dictyocotyle. O, proximal region of ovary 5-7 lobed in Dictyocotyle, simple in Calicotyle. $P$, posterior adhesive organ of Dictyocotyle with numerous irregular shallow loculi of various sizes; of Calicotyle with a central stalk and seven peripheral loculi all of similar shape and size; posterior adhesive organ in Dictyocotyle reaches posterior border of body, in Calicotyle it projects well beyond the posterior margin of the body. $V$, vaginae pass obliquely anteriorly to open in front of vitellaria in Dictyocotyle, but pass transversely in Calicotyle. 